Full-text Available Online at www.ajol.info and www.bioline.org.br/ja
J. Appl. Sci. Environ. Manage. Sept, 2015

Vol. 19 (3) 361 - 372

\title{
Physico-Chemical Characterization and Pollution Index Determination of Leachates from Warri Waste Dumpsite, Southern Nigeria
}

\author{
AGBOZU, IE; ' OGHAMA, OE; ODHIKORI, JO \\ Department of Environmental Science, College of Science, Federal University of Petroleum Resources, Effurun (FUPRE), P.M.B. 1221, \\ Effurun, Nigeria \\ "Corresponding Author, email: iwekumo@yahoo.co.uk; tel: +234-8035426708
}

\begin{abstract}
This study characterizes the leachates quality of an active dumpsite in Warri, Delta State and also analyses its contamination or pollution potential. Leachate Pollution Index (LPI) - a tool for quantifying pollution potential of leachates generated from dumpsites - has been used to quantify the leachates contamination potential of the dumpsite. The LPI values for the different sample locations L1, L2 and L3 were computed to be 5.69, 6.18 and 5.89 respectively with a mean value of 5.80 , while the control had a value of 4.82 . These LPI values were also compared with the LPI standard (7.38) for treated leachates. Comparison of the mean LPI value (5.80) with the standard (7.38) indicated a relatively low contamination potential of the leachates. Moreover, it was observed that the concentration of the individual parameters of the leachates is quite variable. The organic strength $\left(\mathrm{BOD}_{5}\right.$ divided by $\left.\mathrm{COD}\right)$ of the dumpsite was less than 0.5 , while the $\mathrm{pH}$ values indicated that all sample locations in terms of age was mature, an indication of dumpsite stabilization. The study recommends continuous monitoring of leachates and upgrade to an engineered landfill to forestall possible pollution problems in future. CJASEM
\end{abstract}

http://dx.doi.org/10.4314/jasem/v19i3.4

KEYWORDS: Dumpsites, Leachates, Leachate Pollution Index, Leachates Quality, Municipal Solid Waste, Physico-chemical Parameters, Warri

\section{INTRODUCTION}

Nigeria is pestered by a myriad of environmental issues, of which a lack of proper solid waste management system is chief. The annual generation of municipal solid wastes (MSW) in Nigeria is 25 million tonnes (Ogwueleka, 2009) and this may increase due to rapid urbanization and population growth rate. Improper management of solid wastes has resulted in serious ecological, environmental and health problems. Landfills are primary means of MSW disposal in many countries worldwide because they offer dumping high quantities of MSW at economical costs in comparison to other disposal methods such as incineration (Muhammmad et al., 2010). Majority of the MSW disposal sites are still open dumps especially in under developed and developing countries (Susu and Salami, 2011). The absence of proper sanitary (engineered) landfills for disposal of wastes by the local and state governments has given room for the proliferations of open dumps that are scattered in every nook and cranny of the country (Susu and Salami, 2011). These refuse dump sites have become an eyesore to first time visitors to most cities in Nigeria including Warri, one of the hubs of Nigerian oil and gas industry, where the study was undertaken.

Open dumps have been demonstrated by several scholars to pose serious threat to groundwater and surface water resources (Fatta et al., 1999), especially those constructed and operated without impermeable liners to reduce the potential of contamination. They are capable of releasing large amounts of harmful chemicals to nearby water sources and air via leachates and landfill gas respectively (Christensen et al., 2001; Ikem et al., 2002; Alimba et al., 2006). The degree of threat is strongly influenced by the composition of the wastes in the dumpsite, the volume of leachates from the waste mass generated, as well as the location of the dumpsites from water bodies; groundwater and surface water (Slomwcznska and Slomcyznski, 2004). The liquid which is generated as a result of runoff from dumpsites is known as leachates. This accumulates at the bottom of dumpsites and subsequently percolates slowly into the soil to contaminate aquifer beneath it and adjacent surface water bodies. Leachates is a widely used term in the environmental sciences where it has the specific meaning of a liquid that has dissolved or entrained environmentally harmful substances which may then enter the environment and pollute the surrounding water sources and contamination of soil (Khan, 2011). Leachates from dumpsites vary widely in composition depending on the age of the dumpsite and type of waste that it contains. Dumpsite leachates may be characterized as a water based solution of four groups of contaminants; dissolved organic matter (alcohols, acids, aldehydes, short chain sugar etc.), inorganic macro components (common cations and anions including sulphate, chloride, iron, aluminium, zinc and ammonia), heavy metals ( $\mathrm{Pb}, \mathrm{Ni}, \mathrm{Cd}, \mathrm{Hg}$ ), and xenobiotic organic compounds such as 
halogenated organics (PCBs, dioxins etc.) (Christensen et al., 2001, Torabian et al., 2004, and Pivato and Gaspari, 2005). The physical appearance of leachates when it emerges from typical dumpsite is a strongly coloured black, yellow or orange cloudy liquid. The smell is acidic and offensive and may be very pervasive because of hydrogen, nitrogen and sulphur rich organic species such as mercaptans (Singh et al., 2007).

It is therefore expedient that a comprehensive study be carried out on the assessment of pollution levels from these dumpsites, taking into account related parameters, which provide the overall perspectives of the pollution of the dumpsites. This study was therefore aimed at characterizing the leachates quality of a dumpsite in Warri, Delta State and determining its pollution potential, with the view of knowing its content and likely environmental consequences. Leachate Pollution Index (LPI) was used for the assessment of the contamination potential of the leachates. LPI was formulated using Rand Corporation Delphi Technique (Kumar and Alappat, 2003a). The LPI represents the level of contamination potential of a given landfill. It is a single number ranging from 5 to 100 , which expresses the overall contamination potential of a landfill based on severe pollution parameters at a given time. It is an increasing scale index, where a higher value indicates a poor environmental condition (Kumar and Alappat, 2003b). The standard value of LPI is 7.38 (Kumar and Alappat, 2003a).

\section{MATERIALS AND METHOD}

Study Area: This study was carried out in Warri located between latitude $5^{0} 31^{\prime} \mathrm{N}$ and longitude $5^{0} 45^{\prime} \mathrm{E}$. The city is one of the major hubs of petroleum activities and businesses in Southern Nigeria. It is a commercial capital City of Delta State and one of the cosmopolitan cities in Southern Nigeria, comprising originally of Itsekiri, Urhobo and Ijaw people.
The region experiences moderate rainfall and moderate humidity for most part of the year. The area is characterized by tropical equatorial climate with mean annual temperature of $32.8^{\circ} \mathrm{C}$ and annual rainfall amount of $2673.8 \mathrm{~mm}$. There are high temperatures of $36^{\circ} \mathrm{C}$ and $37^{\circ} \mathrm{C}$. The natural vegetation is a rainforest with swamp forest in some areas. The forest is rich in timber trees, palm trees, as well as fruit trees.

The study area is an active dumpsite located at Udu Street along Igbudu road (figure 1). This place can be found behind the popular Igbudu market in Warri, Delta state. This dumpsite serves as the major means of waste disposal to the people of the community, especially the market sellers.

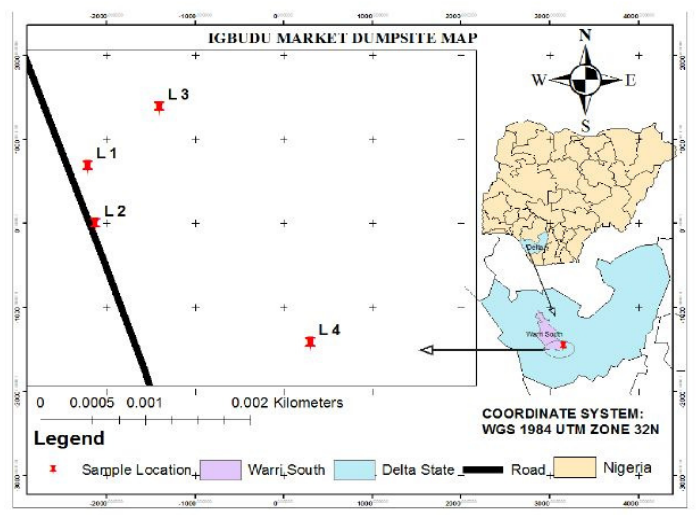

Fig. 1: GIS based Map of Study Area

The coordinates of the locations of the sample in the study area are as shown in Table 1 below:

Table 1: Showing Sample Identification with their GPS Coordinates

\begin{tabular}{cll}
\hline Sample Code & Northings & Eastings \\
\hline L1 & $05^{0} 31^{\prime} 01.4^{\prime}$, & $005^{0} 45^{\prime} 31.0^{\prime}$, \\
L2 & $05^{0} 31^{\prime} 01.3^{\prime}$, & $005^{0} 45^{\prime} 31.0^{\prime}$, \\
L3 & $05^{0} 31^{\prime} 01.5^{\prime}$, & $005^{0} 45^{\prime} 31.1^{\prime}$, \\
L4 (Control) & $05^{0} 31^{\prime} 01.2^{\prime}$, & $005^{0} 45^{\prime} 31.3^{\prime}$, \\
\hline
\end{tabular}
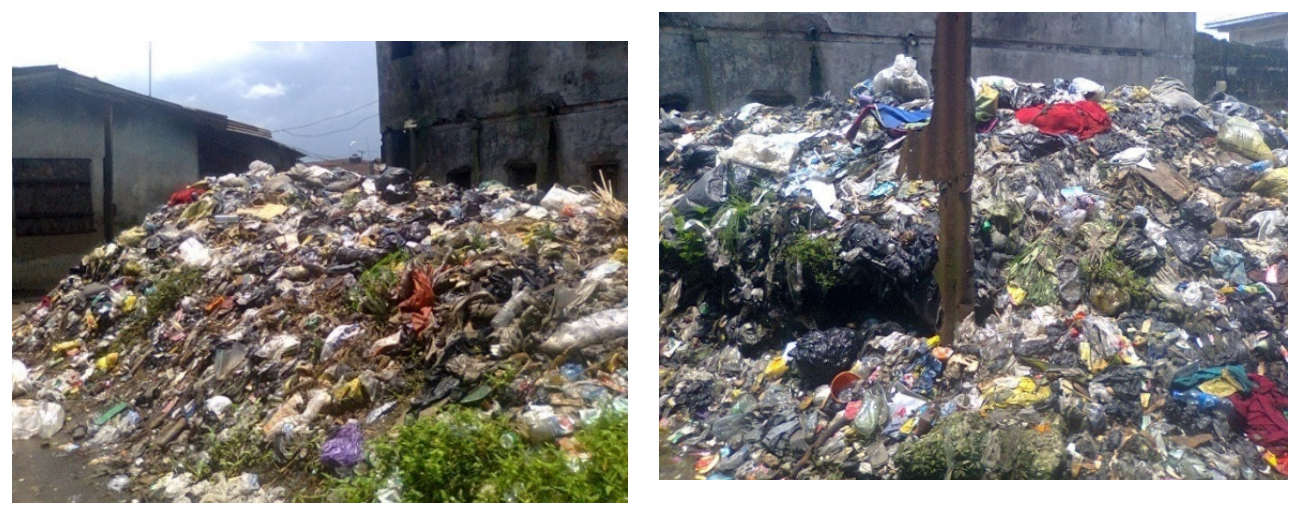

Fig 2: Igbudu market dumpsite, Warri, Delta state 
Sample Collection and Analysis: Leachates samples were collected from 3 trenches dug into the dumpsites with 1 control sample taken outside the dumpsite area (1.5m depth). Since the landfill site was not equipped with a leachates collector, the leachates collected at the base of the landfill was sampled randomly from three different locations. 2-liter plastic containers were used to collect the leachates. Prior to collection, the containers were rinsed with the samples in order to acclimatize to the sample environment.

In order to avoid chemical and biological changes that have the potential to change the natural homogeneity of the samples, the sample for heavy metals analysis was preserved by adding $1 \mathrm{ml}$ of conc. $\mathrm{HNO}_{3}$ while $2 \mathrm{ml}$ Concentrated $\mathrm{H}_{2} \mathrm{SO}_{4}$ was added to samples for COD analysis. The samples were immediately transferred to ice chest and transported to the laboratory for analysis. In-situ parameters such as $\mathrm{pH}$, total dissolved solids and electrical conductivity were measured using Hanna hand held $\mathrm{pH}$ and conductivity/TDS meter.

All the parameters were measured according to the standard method for the examination of water and wastewater by APHA, 2005. pH was determined by glass electrode method with a standard calibrated $\mathrm{pH}$. Dissolved solids, and conductivity were measured in situ. An Atomic Absorption Spectrophotometer was used for metals analyses after samples were digested, using concentrated trioxonitrate $(\mathrm{V})$ and the volume made up to $50 \mathrm{ml}$ with deionized water. BOD was computed from dissolved oxygen (DO) - determined by Azide modification of Winkler's method analyzed over a 5 day period. Open reflux method utilising potassium tetra-oxo chromate (VI) in boiling concentrated tetra-oxosulphate (VI) solution in the presence of silver catalyst was used to determine

\section{RESULTS AND DISCUSSION}

The results obtained from the physico-chemical analyses of leachates from the Igbudu market dumpsite, Warri City municipal dumpsite are presented in Table 2. The organic strength of the dumpsite is shown in Table 3, Table 4 shows the comparison of the mean values of the study with the
COD. Phosphate, chloride and sulphate were analysed by colorimetry using molybdovanadate method.

Calculation of Leachate Pollution Index (LPI): The data from the analyses of samples were used. The ' $P$ ' values or sub-index values for all the parameters analyzed were computed from the sub-index curves based on the concentration of the leachate pollutions obtained during the analysis. The ' $\mathrm{P}$ ' values were obtained by locating the concentration of the leachate pollutant on the horizontal axis of the sub index value where it intersected the curve was noted.

The ' $\mathrm{P}$ ' values obtained for the parameters analyzed were multiplied with the respective weights assigned to each parameters The LPI for each of the dumpsite leachate was calculated using the equation of Kumar and Alappat, (2003a) shown in equations below.

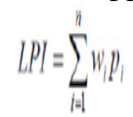

Where, $L P I=$ the weighted additive leachate pollution index, $w i=$ the weight for the $I^{\text {th }}$ pollutant variable, $p i=$ the sub index value of the $I^{\text {th }}$ leachate pollutant variable, $n=18$ and $\sum w i=1$.

However, when the data for all the pollutant variables included in LPI is not available, the LPI can be calculated using data set of the available pollutants by the equation

\section{Where,}

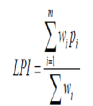

(2)

Where pollutant parameter for which data is available in this study as, $\mathrm{m}<18$ (16) and $\Sigma$ wi $<1$

Nigerian FMENV standard, LPI derived from Kumar and Alappat (2003) computation is presented in Table 5 and Figure 3 while Table 6 shows the comparison of the mean values of the pollutant variables of the dumpsite with the available Leachate Disposal Standards.

Table 2: Concentration of Physicochemical Parameters of leachates from Igbudu Market waste dumpsite

\begin{tabular}{llccccc}
\hline S/N & Parameters & $\begin{array}{c}\text { Location } \\
1(\mathrm{~L} 1)\end{array}$ & $\begin{array}{c}\text { Location } 2 \\
(\mathrm{~L} 2)\end{array}$ & $\begin{array}{c}\text { Location 3 } \\
(\mathrm{L} 3)\end{array}$ & Mean & $\begin{array}{c}\text { Location } 4 \\
\text { (Control) }\end{array}$ \\
\hline 1. & pH & 7.78 & 8.79 & 8.55 & 8.28 & 8.0 \\
2. & TDS $(\mathrm{mg} / \mathrm{l})$ & 348.9 & 630 & 411 & 403.73 & 225 \\
3. & Electrical Conductivity $(\mu \mathrm{s} / \mathrm{cm})$ & 591.2 & $1,254.3$ & 820.7 & 778.18 & 446.5 \\
4. & BOD $(\mathrm{mg} / \mathrm{l})$ & 32.95 & 56.72 & 43.11 & 38.65 & 21.80 \\
5. & COD $(\mathrm{mg} / \mathrm{l})$ & 82.38 & 121.29 & 98.82 & 89.23 & 54.50 \\
6. & Phosphate $(\mathrm{mg} / \mathrm{l})$ & 3.69 & 6.19 & 4.90 & 3.81 & 0.46 \\
7. & Sulphate $(\mathrm{mg} / \mathrm{l})$ & 10.24 & 16.78 & 13.61 & 11.45 & 5.16 \\
8. & Chloride $(\mathrm{mg} / \mathrm{l})$ & 61.70 & 149.37 & 105.13 & 93.16 & 56.42 \\
9. & Nickel $(\mathrm{mg} / \mathrm{l})$ & 0.020 & 0.041 & 0.035 & 0.028 & 0.013 \\
10. & Chromium $(\mathrm{mg} / \mathrm{l})$ & 0.973 & 1.618 & 1.022 & 0.969 & 0.262 \\
11. & Copper $(\mathrm{mg} / \mathrm{l})$ & 0.126 & 0.159 & 0.146 & 0.131 & 0.092 \\
12. & Zinc $(\mathrm{mg} / \mathrm{l})$ & 0.335 & 0.583 & 0.864 & 0.467 & 0.102 \\
13. & Iron $(\mathrm{mg} / \mathrm{l})$ & 2.201 & 8.247 & 5.220 & 4.145 & 0.913 \\
14. & Lead $(\mathrm{mg} / \mathrm{l})$ & 0.094 & 0.121 & 0.106 & 0.0865 & 0.025 \\
15. & Cadmium $(\mathrm{mg} / \mathrm{l})$ & 0.006 & 0.013 & 0.009 & 0.0075 & 0.002 \\
\hline
\end{tabular}


Table 3: Organic Strength $\left(\mathrm{BOD}_{5}\right.$ and COD ratio)

\begin{tabular}{llcccccc}
\hline S/N & Parameters & Location 1 & $\begin{array}{c}\text { Location } \\
2\end{array}$ & $\begin{array}{c}\text { Location } \\
3\end{array}$ & $\begin{array}{c}\text { Mean } \\
\text { Location 4 } \\
\text { (Control) }\end{array}$ & $\begin{array}{c}\text { FMENV } \\
\text { Standard }\end{array}$ \\
\hline 1. & BOD $_{5}(\mathrm{mg} / \mathrm{l})$ & 32.95 & 56.72 & 43.11 & 38.65 & 21.80 & 30 \\
2. & COD $(\mathrm{mg} / \mathrm{l})$ & 82.38 & 121.29 & 98.82 & 89.23 & 54.50 & 75 \\
3. & Organic Strength $=\frac{\text { BOD5 }}{\text { COD }}$ & 0.399 & 0.468 & 0.436 & 0.433 & 0.40 & - \\
\hline
\end{tabular}

Table 4: Comparison of the mean values of the study with the Nigerian FMENV standard

\begin{tabular}{llcc}
\hline S/N & Parameters & Mean & FMENV Standard \\
\hline 1. & pH & 8.28 & $6.000-9.000$ \\
2. & TDS $(\mathrm{mg} / \mathrm{l})$ & 403.73 & NA \\
3. & Electrical Conductivity $(\mu \mathrm{s} / \mathrm{cm})$ & 778.18 & 125.000 \\
$\mathbf{4 .}$ & BOD $(\mathrm{mg} / \mathrm{l})$ & 38.65 & 30.000 \\
$\mathbf{5 .}$ & COD $(\mathrm{mg} / \mathrm{l})$ & 89.23 & 75.000 \\
$\mathbf{6 .}$ & Phosphate $(\mathrm{mg} / \mathrm{l})$ & 3.81 & 50.000 \\
7. & Sulphate $(\mathrm{mg} / \mathrm{l})$ & 7.67 & 100.000 \\
$\mathbf{8 .}$ & Chloride $(\mathrm{mg} / \mathrm{l})$ & 93.16 & 100.000 \\
9. & Nickel $(\mathrm{mg} / \mathrm{l})$ & 0.028 & 5.000 \\
$\mathbf{1 0 .}$ & Chromium $(\mathrm{mg} / \mathrm{l})$ & 0.969 & 0.200 \\
$\mathbf{1 1 .}$ & Copper $(\mathrm{mg} / \mathrm{l})$ & 0.131 & 0.050 \\
$\mathbf{1 2}$ & Zinc $(\mathrm{mg} / \mathrm{l})$ & 0.467 & 5.000 \\
$\mathbf{1 3}$ & Iron $(\mathrm{mg} / \mathrm{l})$ & 4.145 & 0.500 \\
$\mathbf{1 4}$ & Lead $(\mathrm{mg} / \mathrm{l})$ & 0.0865 & 0.010 \\
$\mathbf{1 5}$ & Cadmium $(\mathrm{mg} / \mathrm{l})$ & 0.0075 & 0.010 \\
\hline
\end{tabular}

Table 5: Leachate Pollution Index for L1, L2, L3, LM and L4-C

\begin{tabular}{|c|c|c|c|c|c|c|c|c|c|c|c|c|c|c|c|c|c|}
\hline \multirow[t]{2}{*}{$\begin{array}{l}\mathrm{S} / \\
\mathrm{N}\end{array}$} & \multirow[t]{2}{*}{$\begin{array}{l}\text { Leachate Pollutant } \\
\text { Parameters }\end{array}$} & \multicolumn{5}{|c|}{ Samples Results } & $\begin{array}{l}\text { Variable } \\
\text { Weight }\end{array}$ & \multicolumn{5}{|c|}{$\begin{array}{l}\text { Pollutant Sub Index } \\
\text { Value }\left(\mathrm{P}_{\mathrm{I}}\right)\end{array}$} & \multicolumn{2}{|c|}{$\begin{array}{l}\text { Overall Pollutant } \\
\text { Rating wi.pi }\end{array}$} & \multirow[b]{2}{*}{ L3 } & \multirow[b]{2}{*}{ LM } & \multirow[b]{2}{*}{ L4-C } \\
\hline & & $\mathbf{L 1}$ & L2 & $\mathbf{L 3}$ & $\overline{L M}$ & L4-C & & $\mathbf{L 1}$ & $\mathbf{L 2}$ & $\mathbf{L 3}$ & LM & L4-C & L1 & $\mathbf{L 2}$ & & & \\
\hline 1. & $\mathrm{pH}$ & 7.78 & 8.79 & 8.55 & 8.28 & 8.0 & 0.055 & 5 & 5 & 5 & 5 & 5 & 0.275 & 0.275 & 0.275 & 0.275 & 0.275 \\
\hline 2. & TDS (mg/l) & 348.9 & 630 & 411 & 403.73 & 225 & 0.05 & 5 & 6 & 5 & 5 & 5 & 0.250 & 0.300 & 0.250 & 0.250 & 0.250 \\
\hline 3. & $\begin{array}{l}\text { Electrical } \\
\text { Conductivity }(\mu \mathrm{s} / \mathrm{cm})\end{array}$ & 591.2 & $1,254.3$ & 820.7 & 778.18 & 446.5 & - & NA & NA & NA & NA & NA & NA & NA & NA & NA & NA \\
\hline 4. & $\mathrm{BOD}_{5}(\mathrm{mg} / \mathrm{l})$ & 32.95 & 56.72 & 43.11 & 38.65 & 21.80 & 0.061 & 6 & 7 & 7 & 6 & 5 & 0.366 & 0.427 & 0.427 & 0.366 & 0.305 \\
\hline 5. & $\mathrm{COD}(\mathrm{mg} / \mathrm{l})$ & 82.38 & 121.29 & 98.82 & 89.23 & 54.50 & 0.062 & 8 & 10 & 9 & 9 & 7 & 0.496 & 0.620 & 0.558 & 0.558 & 0.434 \\
\hline 6. & Phosphate $(\mathrm{mg} / \mathrm{l})$ & 3.69 & 6.19 & 4.90 & 3.81 & 0.46 & - & NA & NA & NA & NA & NA & NA & $\mathrm{NA}$ & NA & NA & NA \\
\hline 7. & Sulphate $(\mathrm{mg} / \mathrm{l})$ & 10.24 & 16.78 & 13.61 & 11.45 & 5.16 & - & NA & NA & NA & NA & NA & NA & NA & NA & NA & NA \\
\hline 8. & Chloride $(\mathrm{mg} / \mathrm{l})$ & 61.70 & 149.37 & 105.13 & 93.16 & 56.42 & 0.049 & 5 & 5 & 5 & 5 & 5 & 0.245 & 0.245 & 0.245 & 0.245 & 0.245 \\
\hline 9. & Nickel $(\mathrm{mg} / \mathrm{l})$ & 0.020 & 0.041 & 0.035 & 0.028 & 0.013 & 0.052 & 5 & 5 & 5 & 5 & 5 & 0.260 & 0.260 & 0.260 & 0.260 & 0.260 \\
\hline 10 & Chromium (mg/l) & 0.973 & 1.618 & 1.022 & 0.969 & 0.262 & 0.064 & 7 & 8 & 7 & 7 & 5 & 0.448 & 0.512 & 0.448 & 0.448 & 0.320 \\
\hline 11 & Copper (mg/l) & 0.126 & 0.159 & 0.146 & 0.131 & 0.092 & 0.05 & 5 & 5 & 5 & 5 & 5 & 0.250 & 0.250 & 0.250 & 0.250 & 0.250 \\
\hline 12 & Zinc (mg/l) & 0.335 & 0.583 & 0.864 & 0.467 & 0.102 & 0.056 & 5 & 5 & 5 & 5 & 5 & 0.280 & 0.280 & 0.280 & 0.280 & 0.280 \\
\hline 13 & Iron $(\mathrm{mg} / \mathrm{l})$ & 2.201 & 8.247 & 5.220 & 4.145 & 0.913 & 0.045 & 5 & 5 & 5 & 5 & 5 & 0.225 & 0.225 & 0.225 & 0.225 & 0.225 \\
\hline 14 & Lead (mg/l) & 0.094 & 0.121 & 0.106 & 0.0865 & 0.025 & 0.063 & 6 & 6 & 6 & 6 & 5 & 0.378 & 0.378 & 0.378 & 0.378 & 0.318 \\
\hline 15 & Cadmium (mg/l) & 0.006 & 0.013 & 0.009 & 0.0075 & 0.002 & - & NA & NA & NA & NA & NA & NA & NA & NA & NA & NA \\
\hline ? & TOTAL & & & & & & 0.610 & & & & & & 3.473 & 3.772 & 3.596 & 3.538 & 2.937 \\
\hline & $\begin{array}{l}\text { LPI Value using } \\
\text { Equation } 2\end{array}$ & & & & & & & & & & & & 5.693 & 6.184 & 5.895 & 5.800 & 4.814 \\
\hline
\end{tabular}

Where; L1=Location 1, L2=Location 2, L3=Location 3, LM=Location Mean, L4-C =Location Control, NA $=$ Not Available, NS = No Standard

Table 5 above illustrates the calculation of LPI values from Warri waste dumpsite. Since the data for all the parameters included in LPI are not available, the LPI has been calculated on the basis of the available data. The site specific variation in LPI is shown in Figure 2 below 


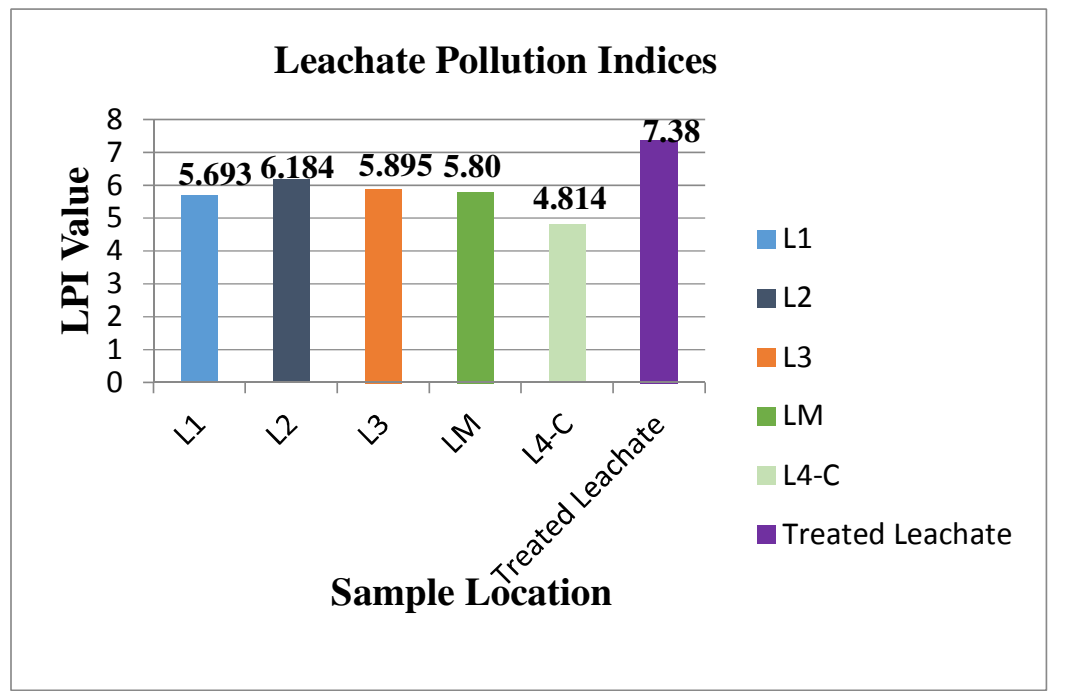

Fig 2: Site Specific Variations in Leachate Pollution Index

Table 6: Comparison of the Mean values of the pollutant variables of the dumpsite with Indian Leachate Disposal Standards (Municipal Solid Waste Management and Handling Rules, 2000)

\begin{tabular}{llcll}
\hline S/N & \multicolumn{1}{c}{$\begin{array}{c}\text { Leachate Pollutant } \\
\text { Parameters }\end{array}$} & Location Mean & $\begin{array}{c}\text { Indian Leachate } \\
\text { Disposal } \\
\text { Standards }\end{array}$ & Remark \\
\hline $\mathbf{1}$ & pH & 8.28 & $5.5-9.0$ & The pH value was within the standard \\
$\mathbf{2}$ & Total Dissolved Solid $(\mathrm{mg} / \mathrm{l})$ & 403.73 & 2100 & The TDS value exceeds the standard \\
$\mathbf{3}$ & Electrical Conductivity $(\mu \mathrm{S} / \mathrm{cm})$ & 778.18 & No Standard & \\
$\mathbf{4}$ & Biological Oxygen Demand $(\mathrm{mg} / \mathrm{l})$ & 38.65 & 30 & The BOD value exceeds the standard \\
$\mathbf{5}$ & Chemical Oxygen Demand $(\mathrm{mg} / \mathrm{l})$ & 89.23 & 250 & The COD value was below the standard \\
$\mathbf{6}$ & Phosphate $(\mathrm{mg} / \mathrm{l})$ & 3.81 & No Standard & \\
$\mathbf{7}$ & Sulphate $(\mathrm{mg} / \mathrm{l})$ & 7.67 & No Standard & The Chloride value was below the standard \\
$\mathbf{8}$ & Chlorides $(\mathrm{mg} / \mathrm{l})$ & 93.16 & 1000 & The Nickel value was below the permissible standard \\
$\mathbf{9}$ & Nickel $(\mathrm{mg} / \mathrm{l})$ & 0.028 & 3.0 & The Chromium value was below the permissible standard \\
$\mathbf{1 0}$ & Chromium $(\mathrm{mg} / \mathrm{l})$ & 0.969 & 2.0 & The Copper value was below the permissible standard \\
$\mathbf{1 1}$ & Copper $(\mathrm{mg} / \mathrm{l})$ & 0.131 & 3.0 & The Zinc value was below the standard \\
$\mathbf{1 2}$ & Zinc $(\mathrm{mg} / \mathrm{l})$ & 0.467 & 5.0 & \\
$\mathbf{1 3}$ & Iron $(\mathrm{mg} / \mathrm{l})$ & 4.145 & No Standard & The Lead value exceeds the permissible standard \\
$\mathbf{1 4}$ & Lead $(\mathrm{mg} / \mathrm{l})$ & 0.0865 & 0.1 & \\
$\mathbf{1 5}$ & Cadmium $(\mathrm{mg} / \mathrm{l})$ & 0.0075 & No Standard & \\
\hline
\end{tabular}

Leachates are generally found to have $\mathrm{pH}$ between 4.5 and 9 (Christensen et al., 2001). The $\mathrm{pH}$ of young leachates is less than 6.5 while old landfill leachates has $\mathrm{pH}$ higher than 7.5 (Abbas et al., 2009). Stabilized leachates shows fairly constant $\mathrm{pH}$ with little variations and it may range between 7.5 and 9 . The $\mathrm{pH}$ values of the leachates samples from the various points ranged from $7.78-8.79$, with a mean value of 8.28 and the control had a value of 8.0. This shows that the leachates are alkaline. The dumpsite can be classified as a representative of an old dumpsite. The $\mathrm{pH}$ value could be attributed to a result of the biological stabilization of the organic matter present in the dumpsite. Chian and DeWalle (1977) reported that the $\mathrm{pH}$ of leachates increased with time due to the decrease of the concentration of the partially ionized free volatile fatty acids. The increase in $\mathrm{pH}$ suggested that a steady state has been reached between acid producing processes (for example, cellulose and lignin degradation) and acid consuming processes (for example, methane formation) at the landfill (Chu et al., 1994). Kulikowsk and Klimiuk (2008); and Tatsi and Zouboulis (2002), reported similar range of $\mathrm{pH}$ from old landfill sites, that is 7.46 - 8.61 and 7.3 - 8.8 respectively. However, the reported values were in variance with Salami et al (2015) who reported a range of 3.96 - 5.01.

TDS comprises mainly of inorganic and dissolved organics. The amount of TDS reflects the extent of mineralization and a higher TDS concentration can change the physical and chemical characteristics of the receiving water (Al-Yaqout and Hamoda, 2003; Muhammad et al., 2010). The TDS of the dumpsites investigated ranged from 225 - $630 \mathrm{mg} / \mathrm{l}$ with L1 having the lowest value and L2 having the highest value. The leachates from L2 can be said to have undergone more mineralization process because of the high value than leachates from L1 and L3 which have lesser values. The leachates from L2 has a very high tendency to change the physical and chemical characteristics of the receiving water more than the leachates from other dumpsites. The values vary significantly from those reported by Agbozu and Nwosisi (2015); and Salami et al (2015) who reported ranges of 70.7 to $4,985.2 \mathrm{mg} / \mathrm{L}$ and 581 to 1,960 $\mathrm{mg} / \mathrm{L}$ respectively. The TDS of this study (a mean of 403.73) is less than the FMENV standard of $500 \mathrm{mg} / 1$. 
The electrical conductivity of the various sampling points are $591.2 \mu \mathrm{s} / \mathrm{cm}, 1,254.3 \mu \mathrm{s} / \mathrm{cm}$ and 820.7 $\mu \mathrm{s} / \mathrm{cm}$ for $\mathrm{L} 1, \mathrm{~L} 2$, and $\mathrm{L} 3$ respectively. The mean concentration was $778.18 \mu \mathrm{s} / \mathrm{cm}$, far exceeding the FMENV standard of $125 \mu \mathrm{s} / \mathrm{cm}$, while the control had a value of $446.5 \mu \mathrm{s} / \mathrm{cm}$. The high value of electrical conductivity in this study is indicative of the presence of inorganic material in the samples. Conductivity is a measure of water's capability to pass electrical flow and is directly related to the concentration of ions, which come from dissolved salts and inorganic materials such as alkalis, chlorides, sulfides and carbonate compounds. The more ions that are present, the higher the conductivity of water. Likewise, the fewer ions that are in the water, the less conductive it is. This means, the leachates from this site contains lots of inorganic material. This is indicative of a high degree of pollution.

The $\mathrm{BOD}_{5}$ values ranged from $21.80 \mathrm{mg} / \mathrm{l}-56.72$ $\mathrm{mg} / \mathrm{l}$ while COD ranged from 82.38 - $121.29 \mathrm{mg} / \mathrm{l}$. The values were in stark contrast to the values reported by Salami et al (2015) who reported ranges of 798 to $1,396 \mathrm{mg} / \mathrm{L}$ and 946 to $1,942 \mathrm{mg} / \mathrm{L}$ for $\mathrm{BOD}_{5}$ and COD respectively. However, Agbozu and Nwosisi (2015) in their study reported much lesser ranges of $1.24-5.95 \mathrm{mg} / \mathrm{l}$ for $\mathrm{BOD}_{5}$ and $3.10-14.87$ $\mathrm{mg} / \mathrm{l}$ for COD. In the initial acidogenic biodegradation stage, the leachate is characterized by high $\mathrm{BOD}_{5}$ and COD (Jones et al., 2006). For stabilized leachates, COD generally ranges between $5,000-20,000 \mathrm{mg} / \mathrm{L}$ (Li and Zhao, 2002). The mean value of the $\mathrm{BOD}_{5}(38.65 \mathrm{mg} / \mathrm{l})$ of the leachates is greater than FMENV standard of $30.00 \mathrm{mg} / \mathrm{l}$ while COD with a mean of $89.23 \mathrm{mg} / \mathrm{l}$ also exceeds the FMENV of $75 \mathrm{mg} / \mathrm{l}$. The $\mathrm{BOD}_{5}$ and $\mathrm{COD}$ values indicate the presence of a high amount of putrescible organic matter in the dumpsite.

Phosphate concentration of L1 was $3.69 \mathrm{mg} / \mathrm{l}$, L2 had $6.19 \mathrm{mg} / \mathrm{l}$, L3 had a concentration of $4.90 \mathrm{mg} / \mathrm{l}$, the control had a concentration of $0.46 \mathrm{mg} / \mathrm{l}$ and the mean concentration for the locations was $3.81 \mathrm{mg} / \mathrm{l}$. The mean concentration fell below FMENV limit of $50 \mathrm{mg} / \mathrm{l}$. The concentration of sulphate for L1, L2, and $\mathrm{L} 3$, are $10.24 \mathrm{mg} / \mathrm{l}, 16.78 \mathrm{mg} / \mathrm{l}$ and $13.61 \mathrm{mg} / \mathrm{l}$. The mean concentration of the points was $7.67 \mathrm{mg} / \mathrm{l}$ and the control value was $5.16 \mathrm{mg} / \mathrm{l}$. The mean concentration fell below the FMENV standard. It falls below FMENV standard of $100 \mathrm{mg} / \mathrm{l}$.

Chloride concentration ranged from $56.42 \mathrm{mg} / \mathrm{l}$ to $149.37 \mathrm{mg} / \mathrm{l}$, with L2 having the highest concentration of $149.47 \mathrm{mg} / \mathrm{l}$, L1 with a concentration of $105.13 \mathrm{mg} / \mathrm{l}, \mathrm{L} 361.70 \mathrm{mg} / \mathrm{l}$ and the control with the lowest value of $56.42 \mathrm{mg} / \mathrm{l}$. The mean concentration of L1, L2 and L3 was $93.16 \mathrm{mg} / \mathrm{l}$, lower than FMENV standard of $100 \mathrm{mg} / \mathrm{l}$. According to Deng and Englehardt (2007), the concentration of chlorides may range between $200-3000 \mathrm{mg} / \mathrm{l}$ for a 1 - 2 year old landfill and the concentration decreases to $100-400 \mathrm{mg} / \mathrm{l}$ for a landfill greater than $5-10$ years old. Hence, the dumpsite can be classified as mature.

Heavy Metals: In the case of heavy metals, the concentration of heavy metals in Landfill leachate is fairly low (Kumar and Alappat, 2003b). From the results of the study, lead ranged from $0.025-0.121$ $\mathrm{mg} / \mathrm{l}$, zinc ranged from $0.102-0.864 \mathrm{mg} / \mathrm{l}$, chromium ranged from $0.262-1.618 \mathrm{mg} / \mathrm{l}$, copper ranged from $0.092-0.159 \mathrm{mg} / \mathrm{l}$, nickel ranged from $0.013-0.041$ $\mathrm{mg} / \mathrm{l}$, iron ranged from $0.913-8.247 \mathrm{mg} / \mathrm{l}$ and cadmium ranged from $0.002-0.013 \mathrm{mg} / \mathrm{l}$. Concentration of heavy metals in a landfill is generally higher at earlier stages because of higher metal solubility as a result of low $\mathrm{pH}$ caused by production of organic acids (Christensen et al., 2001). As a result of increased $\mathrm{pH}$ at later stages, a decrease in heavy metal solubility occurs resulting in rapid decrease in concentration of heavy metals except lead because lead is known to produce very heavy complex with humic acids (Deng and Englehardt, 2007). This support the likelihood of decrease in the concentration of heavy metals in all the dumpsites analysed in later years. However, the solubility and mobility of metals may increase in the presence of natural and synthetic complexing ligands such as humic substances (Jones et al., 2006). The presence complexing ligands in the dumpsites analysed will increase the concentration of heavy metals. In general, the condition in each of the dumpsites investigated determines the concentration of heavy metals in later years.

The lead concentration a mean value of $0.0865 \mathrm{mg} / \mathrm{l}$ exceeded the FMENV acceptable limit of $0.01 \mathrm{mg} / \mathrm{l}$. The mean concentration of zinc $(0.467 \mathrm{mg} / \mathrm{l})$ fell below FMENV limit of $5.00 \mathrm{mg} / \mathrm{l}$. Chromium with a mean value of $0.969 \mathrm{mg} / \mathrm{l}$ exceeded FMENV standard of $0.20 \mathrm{mg} / \mathrm{l}$. The mean copper concentration $(0.131 \mathrm{mg} / \mathrm{l})$ exceeded FMENV limit of $0.05 \mathrm{mg} / \mathrm{l}$. The mean value $(0.028 \mathrm{mg} / \mathrm{l})$ for nickel fell below FMENV standard of $5 \mathrm{mg} / \mathrm{l}$. The mean iron concentration of $4.145 \mathrm{mg} / \mathrm{l}$ exceeded the FMENV limit of $0.50 \mathrm{mg} / \mathrm{l}$. Cadmium concentration of L1, L2, L3 and the mean $(0.0075 \mathrm{mg} / \mathrm{l})$ were all below FMENV limit of $0.10 \mathrm{mg} / \mathrm{l}$.

Though there were variations; some of the heavy metals fell below FMENV while some others exceeded it. There is a significant heavy metals concentration in the leachates from this dumpsite that can pollute the environment.

Strength of Organics $\left(\mathrm{BOD}_{5} / \mathrm{COD}\right.$ ratio $)$ : Organics in leachates are characterized by different levels of biodegradability. Generally, the organic strength describes the degree of biodegradation and gives information on the age of a dumpsite. A decline in $\mathrm{BOD}_{5}$ concentrations can be attributed to a combination of reduction in organic contaminants available for leaching and the increased 
biodegradation of organic compounds (Krug and Ham, 1995). A constant decrease in COD is also expected as degradation of organic matter continues (Ehrig, 1989).

The organic strength is given by;

Organic Strength $=\frac{\text { BOD5 }}{\text { COD }} \quad$ (Rivas et al., 2004; Kurniawan et al., 2006)

The biodegradability of the leachates will also vary with time. Checking the $\mathrm{BOD}_{5} / \mathrm{COD}$ ratio can monitor changes in the biodegradability of the leachates. Ratios in the range from 0.4 to 0.6 are taken as an indication that the organic matter in the leachates is readily biodegradable. For a young landfill, the $\mathrm{BOD}_{5} / \mathrm{COD}$ ratio may be in the range of 0.4 to 0.6 or higher, whereas the ratio in old or matured dumpsites may be in the range of 0.05 to 0.2 suggesting that the organic matter in the leachates is not readily biodegradable.

From Table 3, $\mathrm{BOD}_{5} / \mathrm{COD}$ ratio for the respective locations are $0.399 \mathrm{mg} / 1,0.468 \mathrm{mg} / 1,0.436 \mathrm{mg} / \mathrm{l}$ and $0.40 \mathrm{mg} / 1$, for L1, L2, L3, and L4 respectively, while the mean ratio is 0.433 . This figure $(0.433)$ shows that the organic matter in the leachates is readily biodegradable, and has a high organic strength which can be attributed to fact that the study site is active or open, being fed waste on a daily or continuous basis, which possibly contains organic matter that undergoes biodegradation continually. During the methanogenic phase, the organic strength of the leachates is reduced by methanogenic bacteria such as methanogenic archaea and the concentration of volatile fatty acids also reduces which results in a ratio of $\mathrm{BOD}_{5} / \mathrm{COD}$ less than 0.1 (Rivas et al., 2004; Kurniawan et al., 2006; Deng and Englehart, 2007; Harmsen, 1983). The calculated ratio of 0.433 suggests high organic strength for the dumpsites and this ratio is similar to those obtained by previous researchers (Agbozu and Nwosisi, 2015; Amina, 2004; Baha, 2005; Yoshida et al., 2002). Salami et al, (2015) reported $\mathrm{BOD}_{5} / \mathrm{COD}$ ratio of $1.476,0.54,0.46$ and 0.54 in their study of four dumpsites in Lagos, Nigeria. None of these ratios is less than 0.1 which shows the leachates from all the dumpsites have not reached methanogenic phase. In addition, Irene (1996) asserted that as the age of the landfill increases, the $\mathrm{BOD}_{5} / \mathrm{COD}$ ratio decreases.

Observed Trends in the Physico-chemical Concentrations of Leachates in the Dumpsite

From the results of the leachates analyses carried out on the Igbudu market dumpsite, there were variations in the concentrations of the parameters tested for at the various sampling points; L1, L2, L3, and L4 (control).

From the results obtained, L2 has the highest concentration of the parameters tested for. This may be due to its proximity with the road and hence easier access by the people. It may also be due to the large amount of ash disposed on this point of the study site. This location also has a greater slope which makes leaching more possible down to this point. L3 has the next highest concentration of the physico-chemical and heavy metals parameters tested for. This may be due to the fact that it is at the other edge of the dumpsite with an easy access, hence a greater accumulation of waste. This means it will contain a greater constituent of matter to be leached out of the waste during rainfall or water percolation. L1 has the lowest concentrations of the parameters. It is located in the middle of the dumpsite and had a gentler slope. This means, the degree of leaching from the top would not be so fast or great compared with the other points.

L4 (control) was taken outside the dumpsite, it served as a standard to compare the concentrations of the parameters tested for from the three locations (L1, L2, and L3), within the dumpsite. This location had by far the lowest concentrations of the physicochemical parameters tested for. This may be accounted for to be as a result of the fact that it is outside of the dumpsite and had no form of waste from which any leachates could have contaminated it, at the time of the study.

Thus, L2 can be attributed to be the most contaminated location of the study site.

Analysis of the Pollution Indices of the Dumpsite Leachates: Based on the evaluated results, the LPI for L1, L2 and L3 was found to be 5.69, 6.18 and 5.89 respectively with a mean value of 5.80 while the control had a value of 4.82. Kumar and Alappat (2005) calculated LPI values for two active landfill sites and reported LPI of 36.4 and 39. Their reported values are higher than the observed values in this study. This can be ascribed to the lower individual pollution ratings of the dumpsite due to the relatively low concentrations of $\mathrm{BOD}_{5}, \mathrm{COD}$ and to lesser extent the chlorides than the landfill sites studied by Kumar and Alappat (2005).

Salami et al (2015) calculated LPI values for four dumpsites in Lagos, Nigeria and reported values of $17.85,16.87,18.99$ and 23.54. Their values were far higher than the results of this study and also the LPI standard and as a result offered a veritable cause for concern. Urgent remediation measures were advised as the dumpsites were adjudged to pose serious threat to public health and the environment.

Agbozu and Nwosisi (2015) also calculated LPI values for three dumpsites (one active and two closed dump sites) within Port Harcourt metropolis in Nigeria. They reported LPI values of 3.91 and 4.71 for the two closed dumpsites and 7.12 for the active dumpsite. They advised that though all the values fell below the LPI standard of 7.38, immediate attention should be given to the active dumpsite in order to avoid a big pollution incident to the environment and threat to human health. Their reported values for the closed dumpsites were understandably lower than the 
values of this study (being an active dumpsite), while the value of the active dumpsite in their study was higher than the value of this study.

Moreover, it can be depicted that the comparatively low values of the LPI for a landfill site is attributed to low concentrations of heavy metals in the samples. Landfill age also plays an important role in the leachates characteristics and hence, influences the LPI value (Lo, 1996).

Comparison with Standards: Nigeria has no known leachates disposal standard and as a result, a standard in India has been used. The Indian standards for the disposal of treated leachates to inland surface water as per Municipal Solid Waste (Management and Handling) Rules, 2000 for the various parameters are presented and compared with the mean values of the pollutant variables of the dumpsite in Table 6 above.

Comparing the analysed parameters in all dumpsites investigated with the leachate disposal standard, it was observed that the concentrations of all the parameters of the leachates fell below the permissible limits of treated leachates discharged into inland surface water except TDS, BOD and Lead; while there were no standards to compare electrical conductivity, phosphate, sulphate, iron, cadmium and manganese values with.

The LPI value of the standards for the treated leachates is calculated and reported in Table 5. The LPI value of the treated leachates shall not exceed 7.38. The comparison of the leachates characteristics with the standards set for the disposal of treated leachates shows that the leachates generated from the dumpsite is mildly contaminated. The low values of LPI 5.69, 6.18 and 5.89 (all below 7.38) indicate the relatively low contamination potential of the leachates. However, the individual contaminants shall meet the discharge standards before discharge of leachates into any surface water body (Rafizul et al, 2011).

\section{Environmental and Health Implications}

Leachates have the possibility of leaching to groundwater or possibly to surface water. Once this occurs, the water becomes polluted and if consumed can lead to health implications. The concentration of total dissolved salts (TDS) gives an idea about the nature of quality and or the salinity of the water. According to WHO (2004), high level of TDS may be responsible for reduction in the palatability of water, inflict gastro-intestinal inconveniences in human and may also cause laxative effect particularly upon transits. The result of the analysis showed high values for the TDS which can cause any of the diseases mentioned above. The electrical conductivity (EC) of water is reflection of the quantity of ionic constituents dissolved in it. Once the leachates percolate, it increases the electrical conductivity of the water in contact and therefore reduces the potability of the water. A minute value of phosphate as low as $0.01 \mathrm{mg} / 1$ in groundwater may result in the water being slimy and also promotes the growth of algal (Adekunle et al., 2007). High quantity of sulphates in water is dangerous as it causes dehydration and diarrhea in children than adults (Longe and Balogun, 2010).

According to WHO (1997), high concentration of chlorides is detrimental to people with heart diseases and Kidney problem. The dumpsite is also prone to generation of gas and therefore violent explosions. Odour is also generated from the site which makes dwellers around the area uneasy. Fire is a common thing in this dumpsite as a result of methane gas generations and also the use of chemicals. Leachates cause decrease of soil $\mathrm{pH}$ and increase the electrical conductivity of the soil (Panahpour et al., 2011). Heavy metals could also be accumulated in the crops planted within the area.

Conclusion: From the results obtained, the $\mathrm{pH}$, temperature, phosphate, sulphate and chloride fell below the FMENV limits while electrical conductivity, BOD and COD exceeded the limits. Some of the heavy metals (nickel, zinc and cadmium) fell below FMENV limits while the others (chromium, copper, iron, lead) exceeded it. Pollution of the environment and health implications is very possible as a result of the presence of the dumpsite around residential areas.

Furthermore, though the mean $\mathrm{pH}$ of the dumpsite is indicative of a mature dumpsite, the organic strength $\left(\mathrm{BOD}_{5} / \mathrm{COD}\right.$ ratio) of $0.433 \mathrm{mg} / \mathrm{l}$ is characteristic of a young dumpsite. This variation can be attributed to continuous biodegradation due to the daily disposal of wastes on the dumpsite. Hence, it cannot be classified as either young or mature; it is best described as intermediate (between 5-10 years old).

The concentrations of the parameters of the leachates except TDS, BOD and lead fall below the permissible limits of treated leachates discharged into inland surface water. The comparison of the leachates characteristics with the standards set for the disposal of treated leachates indicate a relatively low contamination potential of the leachates as the LPI values of all the sample location falls below value for treated leachates (7.38). It is however recommended that individual contaminants meet the discharge standards before discharge.

Finally, it is suggested that the waste management board of the state and the local government council should partner to upgrade the dump site and others into well engineered landfills.

\section{REFERENCES}

Abbas, A. A., Jingsong, G., Ping, L. Z., Ya, P. Y. and Al-Rekabi, W. S. (2009). Review on Landfill 
Leachate Treatments. Am. J. Applied Sci., 6: 672684.

Adekunle, I. M., Adetunji, M. T., Gbadebo, A. M., and Banjoko, O. B. (2007). "Assessment of Groundwater Quality in a Typical Rural Settlement in Southwest, Nigeria". Int. Journal of Environment and Public Health. 4(4): 307318.

Agbozu, I. E., and Nwosisi, C. (2015). Determination of Pollution Index between Active and Closed Dumpsites in Port Harcourt Metropolis. J. Chem. Bio. Phy. Sci. Vol. 5, No 2; 2051-2061.

Amina. C., Abdekader, Y., Elkbri, L., Jacky, M., Alain, V. (2004). Environmental Impact of an Urban Landfill on a Costal Aquifer (El Jadida Morocco). J Afr. Earth Sci. 39,509-516.

Alimba, C. G., Bakare, A. A., and Latunji, C. A. (2006). Municipal landfill leachates induced chromosome aberrations in rat bone marrow cells. Afr. J. Biotech., 5(22): 2053 - 2057.

Al-Yaqout, A. F. and Hamoda, M. F. (2003). Evaluation of landfill leachate in arid climate. Environmental International. 29(5):593600.

American Public Health Association (2005). Standard methods for the examination of water and waste water.Washington, DC, USA.

Bahaa, E. W. (2005). The migration of inorganic contaminants from landfill sites into the soil and groundwater system. Master thesis, Universiti Kebangsaam Malaysia.

Chian, E. S. K. and DeWalle, F. B. (1977). "Evaluation of leachate treatment, vol. 1, characterization of leachate." EPA-600/2-77186a, US Environmental Protection Agency, Cincinnati.

Christensen, T. H., Kjeldsen, P., Bjerg, P. L., Jensen, D. L., Christensen, B. J., Baum, A., and Albrechtsen, H. G. (2001). Biogeochemistry of Landfill Leachate Plumes. Applied Geochem., 16:659-718.

Chu, L. M., Cheung K. C., and Wong M. H. (1994). "Variations in the chemical-properties of landfill leachate." Environ. Manag. 18, 105.

Deng, Y. and Englehardt, J. D. (2007). Electrochemical oxidation for landfill leachate treatment, Waste Management, 27(3):380-388.

Ehrig, H. J. (1989). "Leachate quality in Sanitary Landfilling: Process, Technology, and Environmental Impact." T.H. Christensen, R.
Cossu, and R. Stegman, Eds.; Academic Press, New York, 1989.

Fatta, D., Papadopoulos, A., and Loizidou, M., (1999). A Study on the Landfill Leachate and Its Impact on the Groundwater Quality of the Greater Area.Environment Geochemistry and Health 21(2):175-190.

Harmsen, J. (1983). Identification of organic compounds in leachate from a waste tip. Water Research. 17(6):699-705.

Ikem, A., Osibanjo, O., Sridhar, M. K. C.and Sobande, A. (2002). Evaluation of groundwater quality characteristics near two waste sites in Ibadan and Lagos, Nigeria. Water-Air-Soil Pollut., 140: 307-333

Irene, M. C. (1996). Characteristics and treatment of leachates from domestic landfills. Environmental International 22 (4):433-442.

Jones, D. L., Wiliamson, K. L., and Owen, A. G (2006). Phytoremediation of landfill leachate. Waste Management. 26(8):825-837.

Khan, F. R., (2011). Study of Ground Water Pollution.M.Tech. Thesis. Department of Civil Engineering. University Raipur(India): 6-12.

Kulikowska, D. and Klimiuk, E. (2008). "The effect of landfill age on municipal leachate composition: review and opportunity. Bioresource Technology. 99(13):5891- 5985.

Kumar, D., and Alappat B. J. (2003a). Analysis of leachate contamination potential of a municipal landfill using leachate pollution index. Workshop on sustainable landfill management, India. 3(5): 147-153.

Kumar, D., and Alappat, B. J. (2003b). A technique to quantify landfill leachate pollution.Ninth International Landfill Symposium, October 2003, Cagliari, Italy.

Kumar, D. and Alappat, B. J. (2005). Evaluating leachate contamination potential of landfill sites using leachate pollution index. Clean Technologies and Environmental Policy, 7(3): 190-197.

Kurniawan, T. A., LO, W. H., and Chan, G. Y. S. (2006). Physico-chemical treatments for removal of recalcitrant contaminants from landfill leachate. Journal of Hazardous Materials. 129(3):80-100.

Krug, M. N. and. Ham R. K. (1995). "Analysis of long-term leachate characteristics in Wisconsin 
landfills." Presented at the Eighteenth International Madison Waste Conference, Department of Engineering Professional Development, Madison.

Li, X. Z. and Zhao, Q. L (2002). Map precipitation from landfill leachate and seawater bittern water. Environmental Technology. 23(9):989-1000.

Longe, E. O., and Balogun, M. R., (2010). Groundwater Quality Assessment near a Municipal Landfill, Lagos, Nigeria. Research Journal of Applied Science, Engineering and Technology, 2(1):39-44.

Muhammmad, U., Hamidi, A., and Mohd, S. Y. (2010). Variability of parameters involved in leachate pollution index and determination of LPI from four Landfills in Malaysia. International Journal of Chemical Engineering. DOI.1155/2010/747953.

Municipal Solid Wastes (Management and Handling) Rules, 2000. Ministry of Environment and Forests Notification, New Delhi.

Ogwueleka, T. C. (2009). "Municipal solid waste characteristics and management in Nigeria," Iran J. Environ. Health Sci. Eng., 6(3): 173-180.

Ohwoghere-Asuma, O., and Aweto, K. E. (2013). Leachate Characterization and Assessment of Groundwater and Surface Water Qualities near Municipal Solid Waste Dump Site in Effurun, Delta State, Nigeria. Journal of Environment and Earth Science, ISSN 2224-3216, Vol. 3, No.9.

Panahpour, E., Gholami, A., Davami, A. H. (2011). Influence of Garbage Leachate on Soil Reaction, Salinity and Soil Organic Matter in East of Isfahan. World Academy of Science, Engineering and Technology, 171-176.

Pivato, A. and Gaspari, L., (2005). Acute Toxicity Test of Leachates From Traditional And Sustainable Landfills Using Luminescent Bacteria. Waste Manage., 26: 1148-1155.

Rafizul, I. M., Alamgir, M. and Islam, M. M. (2011). Evaluation of Contamination Potential of Sanitary Landfill Lysimeter using Leachate Pollution Index. Proceedings Sardinia, Thirteenth
International Waste Management and Landfill Symposium.

Rivas, F. J., Beltran F., Carvalho, F., Acedo, B., and Gimeno, O. (2004). Stabilized leachates sequential coagulation-flocculation + chemical oxidation process. Journal of Hazardous Materials. 116(2):95-102.

Salami, L., Fadayini, O., Patinvoh, R.J. and Koleola, O. (2015). Evaluation of Leachate Contamination Potential of Lagos Dumpsites Using Leachate Pollution Index. British Journal of Applied Science \& Technology. 5(1): 48-59

Singh, A., Chandra, S., Kumar Gupta, S., Chauhan, L. K., and Kumar Rath, S., (2007). Mutagenicity of Leachates From Industrial Solid Wastes Using Salmonella Reverse Mutation Assay. Ecotoxicol Environ Saf. 66(2):210-6.

Susu, A. A. and Salami, L. (2011). Proposal for joint research efforts with the Ministry of Environment on surface and ground water contamination and remediation near municipal landfill site, Lagos, Nigeria. 1-2.

Tatsi, A. A. and Zouboulis, A. I. (2002). A field investigation of the quantity and quality of Leachate from a municipal solid waste landfill in a mediteranean climate. Advances in Environmental Research. 6(3):207-219.

Torabian, A., Hassani, A.H., Moshirvaziri, S., (2004). Physicochemical and Biological Treatability Studies of Urban Solid Waste Leachate. International Journal of Environmental Science \& Technology, 1(2), 103-107.

WHO. (1997). Guideline for drinking water quality, 2nd ed., Vol 2 Health criteria and other supporting information, World Health organization, Geneva, pp 940-949.

WHO. (2004). Guidelines for Drinking-Water Quality. Geneva. Third Edition Volume 1. Recommendations.

Yoshida, M., Sothom A., Souissi, N., Bousselmi, L., Jedidi, N., Ghrabi, A., and Ferchichiand, M. (2002). Characterization of leachate from Henchir El Yahoudia closed landfill. Water, Waste and Environment Research 1(2): 129-142. 
APPENDIX

Appendix A: The averaged sub index curves of pollutant
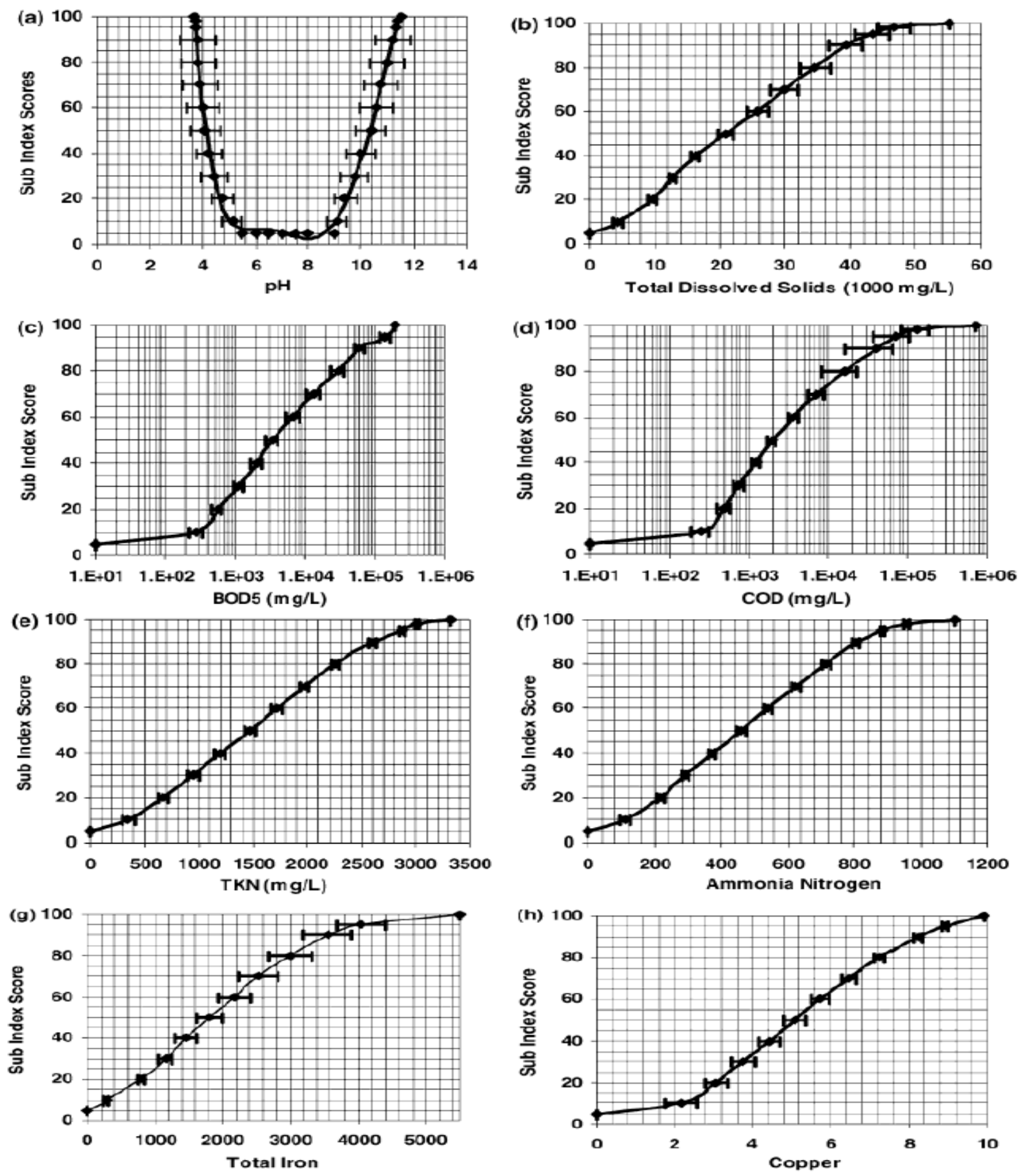

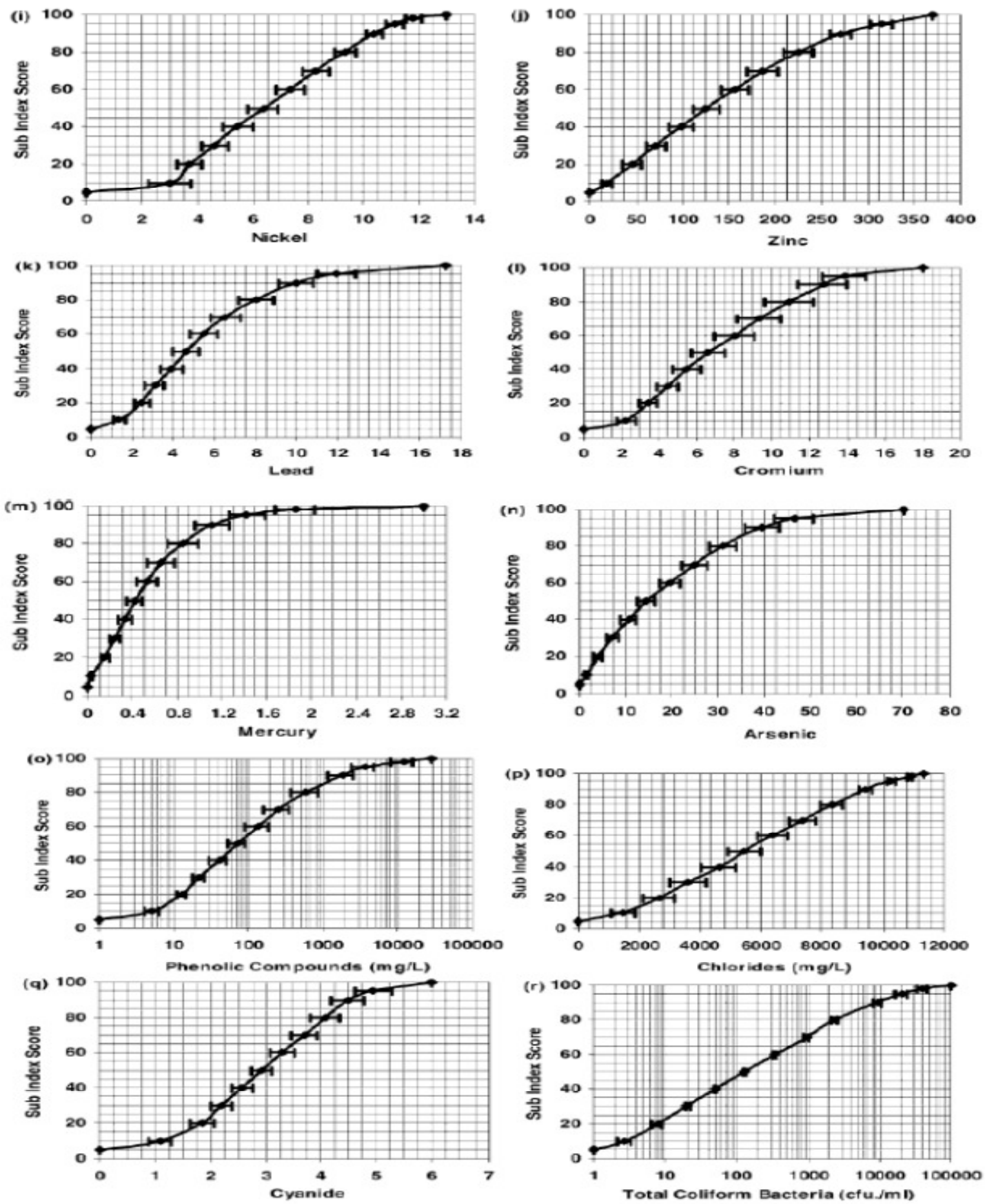

The averaged sub index curves of pollutant (a) pH (b) TDS (c) $\mathrm{BOD}_{5}$ (d) COD (e) TKN (f) Ammonium nitrogen (g) Iron (h) Copper (i) Nickel (j) Zinc (k) Lead (l) Chromium (m) Mercury (n) Arsenic (o) Phenol (p) Chlorides (q) Cyanide (r) TCB (after Kumar and Alaappat, 2003). 